\title{
KUSPER JUDIT
}

\section{AZ ABSZURDITÁS REALITÁSA PINTÉR BÉLA FÁCÁNTÁNC CÍMÜ DRÁMÁJÁBAN ${ }^{1}$}

Az embert évezredek óta foglalkoztatja a trauma kimondása, feldolgozása, jelenvalóvá tétele, színrevitele. Pintér Béla drámái immár több évtizede kínálják a jelen és a múlt, a külső és a belső világ tragédiáinak, kérdéseinek megjelenítését, a drámai szituációkba helyezett élethelyzetek megértését, vagy éppen a távollévő vagy soha meg nem történt allegorikus viszonyrendszerbe helyezését. Mi, olvasók és nézők pedig keressük a mondatokat és jeleneteket, melyek minket szólítanak meg, idegenségükben vagy abszurditásukban a nagyon is sajátra és közelire ismerünk, rácsodálkozunk egy abszurd világra, kinevetjük a képtelenségeket, de közben lehetőségünk nyílik arra is, hogy saját világunkat értsük meg a végletekig vitt nyelvjátékok, túlszcenírozott jelenetek segítségével.

Pintér Béla Fácántánc ${ }^{2}$ című drámája egy fiktív világ fiktív problémáit jeleníti meg, ám az ábrázolás eszközei, a problémák természetrajza vagy éppen a mü szereplői korántsem tekinthetők idegennek vagy fiktívnek. Összetett nyelvi és tropologikus játéka ugyanakkor müfaji sokszínűséget is jelent, melynek segítségével választott címbeli fogalmunkat, az abszurditás realitását is igyekszünk értelmezni.

\section{Múfajok (össz)játéka}

A Fácántánc műfaji besorolása egyszerre egyszerű és bonyodalmakba ütköző: több kapcsolódási pontot is találunk a klasszikusan értelmezett műfaji jegyekkel, ám mindig tetten érhetünk egy kis elmozdulást is, mely rögtön felszámolja a hagyományos kereteket. Olvashatjuk a müvet társadalmi drámaként, hiszen egy adott társadalom, illetve a különböző társadalmi csoportok problémái, a közöttük kialakuló feszültség szervezi a cselekményt. A társadalmi dráma színre viszi a társadalmi-politikai kérdésekre adott válaszokat (vagy éppen a válaszok hiányát), hősei sokszor allegorikus figurák, melyek egy-egy eszme szócsövei lehetnek. Ilyen múvekkel találkozhatunk Molière-nél, de Csokonai Vitéz Mihály, Kisfaludy Károly vagy Henrik Ibsen drámái is pontos, ám egyben groteszk képet is festenek a társadalom visszásságairól.

1 A kutatást az EFOP-3.6.1-16-2016-00001 „Kutatási kapacitások és szolgáltatások komplex fejlesztése az Eszterházy Károly Egyetemen" című projekt támogatta.

2 PINTÉR Béla, „Fácántánc”, in PINTér Béla, Újabb drámák, 111-157 (Budapest: Saxum Kiadó, 2018). A későbbiekben e kiadásra hivatkozom az oldalszám megjelölésével. 
A valódi társadalmi problémák feltárását persze mindig nehezíti az egyidejüség, a perspektíva hiánya, így sokszor találkozunk nyelvi vagy tematikus eltávolítással, illetve a műfaj dekonstruálásával. Ilyen eltávolítás az, amikor a jelen problémáit egy múltbéli esemény allegóriáin keresztül jelenítjük meg, vagy épp a közelmúlt válik a mű időkeretévé. Ezen esetekben megteremtődik ugyan a történelmi dráma müfaja, ám elsősorban retorikai keretként, a társadalmi dráma kitágított színtereként. E két drámatípus a magyar irodalomtörténetben (is) szinte elválaszthatatlan egymástól, funkcióját tekintve pedig mindkettő az eltávolításon (képpé tevésen) keresztüli megértést fogja elősegíteni. Kétségtelen, hogy a jelen megértése, kérdéseinek felvetése sohasem egyszerü, hiszen nehezen találjuk meg a kívülről való, így elvonatkoztató szemlélés legmegfelelőbb perspektíváját. Egy irodalmi mü, jelen esetben egy dráma viszont sajátos poétikai eszközei segítségével átlépheti e határokat, s mind poétikai, mind retorikai szinten új nézőpontokat teremthet, ahonnan az eltávolított valóság egyszerre hozza létre az idegenségben lakozó absztrakció lehetőségét és az ismerősség megnyugtató feloldását.

Így válhat tehát egy társadalmi kérdés egy történelmi dráma fókuszává, ám ezzel együtt már létre is jön az allegorikus dráma múfaji kerete: a múlt (vagy bármely történelmi időhorizont) önmagán hordozza a jelenre vonatkozás jeleit. A Fácántánc esetében tovább finomíthatjuk e fogalmat, hiszen a történelmi távlat fiktív, összegyúrása a török hódoltság, a jelen és egy fiktív jövő horizontjának. Ez a fikcionáltság így át is írja tehát az eddig felvázolt kereteket, s közel viszi a 20. század közepének abszurd drámáihoz. A drámában megteremtődő világ pedig újabb, elsősorban az epikában ismert műfaji jegyet csempészhet be, méghozzá a disztópiák világát, melyen képzeletbeli (rossz) helyeket hoznak létre, többnyire egy letünt kultúra romjaira, maradványaira építve.

Láthatjuk, hogy a műfaj sokrétűségét mind az allegorikus szint, mind az abszurditás uralja, folyamatosan lehetőséget kínálva a műben teremtett (nyelvi) világ sokrétű dekódolására. A reális világ jelei úgy állnak össze, hogy egy abszurd imaginárius világ bontakozik ki, melynek szereplői erősen átírják a klasszikus drámák hősfogalmát is, s közelebb állnak a 19. század végi társadalmi drámák (Ibsen, Csehov), a 20. századi társadalmi-történelmi drámák (Sarkadi, Nádas Péter), és persze a groteszk és abszurd drámák (Ionesco, Beckett, Örkény, Spiró) „,hőstelenített" hőseihez.

Pintér múve már a címében, illetve idő- és helymeghatározásában is belépteti az olvasót e többrétegű, önmagát megkérdőjelező és elbizonytalanító világba. A Fácántánc mint cím nem csak saját szemantikai jegyeit mutatja fel (egy fácán tánca), hanem felhívja a figyelmet valaminek a hiányára: olyan, mintha a metaforikus pávatánc helyett állna itt a cím. A pávatánc az önmagát kellető, eladó, magát másnak, jobbnak mutató személy cselekedeteinek metaforája, mely összekapcsolódásban a Pintér-darab címében szereplő fácán majdnem olyan, mint a páva, de mégsem olyan előkelő, nem olyan színes, nem olyan méretes, nem olyan díszes, kicsit kelet-európai, hiányoznak róla a valódi díszek. A metaforikus képösszekapcsolás ezért hiányosan, vagy inkább transzpozíció- 
ban valósul meg: a pávatánc helyére lépő fácántánc így egyrészt fel is idézi a pávatánc jelentésfelhőjét, ugyanakkor rögtön ironizálja, meg is kérdőjelezi. E feszültség generálja a cím jelentésrétegeit, mely így szükségképpen groteszkként implikálja e paratextus és a szöveg kapcsolatát.

A dráma ideje és helyszíne ugyancsak magán hordozza azt az elbizonytalanítást, amit a műfaji meghatározás esetében már láthattunk: „Játszódik egy képzeletbeli korban, egy képzeletbeli nevelőintézetben." (112.) E képzeletbeli kor ugyanakkor igen pontos meghatározást is kap: 1695-ben, a százötven éves török uralom lezárulása után, az 513. számú Simon Ferenc Állami Nevelőintézet és Szakmunkásképzőben járunk, ám valóban képzeletbelivé válik mind az idő, mind a helyszín: ez nem az a török uralom, ez nem az az osztrák felszabadító csapat, ez nem az a Magyarország, amit a 17. századi történelemről tanultak során megismerhettünk. Minden összecsúszik a ma és a közelmúlt eseményeivel, mind a történelem, mind annak kellékei különös elegyét hozzák létre anakronisztikusnak, reálisnak és fantasztikusnak. Képileg mindez egy újabb műfaj, a cyberpunk felidézését is lehetővé teszi. A történelmi 17. század díszletei (a német Andreas barokk férfikalapja, a diákok török turbánjai, kendői) különös elegyet alkotnak a 20. század technikai vívmányaival (mikrofon, hangosítás, repülőgép), a közelmúlt történelmének társadalmi formáció pedig ugyancsak ráíródnak a hódoltság utáni időszak berendezkedésére: a Simon Ferenc leginkább egy bentlakásos szakmunkásképzőre emlékeztet, a szocializmus struktúrájának megfelelően úttörőcsapattal, csapatzászlóval, jelentéssel stb.

A mű abszurditása elsősorban az ábrázolt világ sokszínűségéből, azon túl pedig sokalapúságából fakad. Semmi nem az, aminek látszik, az olvasó/néző már éppen otthon érezné magát az ábrázolt világban, az ismerősség jeleit fedezi fel akár történelmi ismereteire, akár a közelmúltra, akár a jelen politikai berendezkedésére építve, ám mindez összegyúrva egy olyan sajátos miliőt teremt, melynek határai szükségszerüen elmosódnak, mintha itt minden lehetséges lenne, hiszen az észszerüség már semminek nem szab határt. Az 1695-ben játszódó történetben békésen megfér egymás mellett a holokauszt emléke, a rendszerváltás problémája, az Azték Birodalom motívumkincse vagy éppen olyan kortárs társadalmi jelenségek, mint a feminizmus, a drog vagy a korrupció.

De nézzük meg közelebbről, hogyan épülhet fel egy ily szövevényes allegorikus hálóra egy társadalmi-történelmi-abszurd-cyberpunk dráma! Egy allegorikus háló sok-sok különböző szálból tevődik össze, most megkíséreljük e szálakat felderíteni, hogy végül újra összeszőjük őket. Fontos ugyanakkor kiemelni, hogy az egy-egy, tematikus, poétikai vagy retorikai alapokra épülő allegorikus szál önállóan is komplexen felépített, ám valódi jelentésüket egybeszőve, egymással párbeszédet folytatva érik el. 


\section{Saját tradíció}

Az említett időben és helyen árva gyerekek (és felnőttek) élnek egy bentlakásos nevelőintézetben - talán éppen a százötven éves török uralom alatt veszítették el családjukat. A nagy család így a Simon Ferenc lakóiból épül fel, ahol nincs se szülő, se nagyszülő, csak igazgató és állami gyám. A valódi családi szokások átadják helyüket a látszatkapcsolatoknak, érzelmi viszonyok helyett egészségtelen anya-gyermek kapcsolat (vagy inkább annak paródiája) bontakozik ki a gyerekek (fiatal felnőttek) és az igazgatónő között, aki az esti puszit is zsarolásra, a puszimegvonást pedig büntetésként használja.

A török hordákat éppen kiǔzték a németek, így az iskola irányítása, az iskolarendszer kiépítése is az ő kezükbe kerül: egyik napról a másikra megváltoznak a szokások és szabályok, mind külsőségeiben (le kell vetniük a török kendőt, turbánt), mind módszereiben (tilos lesz a gyerekek testi fenyítése). Az iskola saját tradícióit ugyanakkor elkerülik e változások: az igazgatónő fácántollas, árvalányhajas azték fejdísze, a beavatási szertartás dala és mozzanatai annyira elkülönülnek mindkét nagy paradigmától, hogy sem a régi, sem az új nem kezdett vele semmit, nem tekintette a maga szempontjából veszélyesnek, így egyfajta magánmitológia részévé válik, mely a Simonosok identitását képes mindvégig megőrizni. Ősi imájuk túléli mind a török, mind a német uralmat, metafizikájuk stabilitását ez adja (126.):

„GYÖNGYI: Nagy szellemünk, Szimoquál, ki az azték tollas kígyó gyermekeként születtél fácántestben, kérünk, jelenj meg nekünk!

PETI: $\quad$ Ki 1552-ben egészen Szolnokig repültél,

PÖTYI: Ki Szolnokon fácánból emberré váltál, és felvetted a Simon Ferenc nevet,

GYÖNGYI: Ki a Szolnoki Vár eleste után foltozóvargaként az Egri Vár védelmére siettél,

PETI: $\quad$ Ki Dobó Istvánnak csúszásmentes harci bakancsot varrtál,

PÖTYI: Ki minden éjjel fácánná változtál, és a vár fölé emelkedve kikémlelted a törökök mozgását,

MIND: Kérünk, jelenj meg nekünk!"

E mitológiára építve jött létre maga az iskola is, ahol tornacipőket varrnak, az alsóbb évfolyamokon kézzel, az ügyesebbek géppel. S magánmitológiájukat továbbépíti a közelmúlt néhány szerencsés/szerencsétlen véletlene: a törökök zsarnok fővezére, Első Szelim oktatási reformjának megroppanásában nagy szerepet játszott az iskola, hiszen a vezér először szélütést kapott, amikor a Simon diákjainak tanulmányi eredményeit olvasta, majd az iskolában varrt tornacipőben megcsúszott és életét vesztette. Második Szelim már nem tudott elég erős rezsimet kiépíteni, így a németek könnyűszerrel el tudták őket űzni az országból. 


\section{Török világ - német világ}

Az iskola a Kanizsai Vilajetből átkerült a Nyugarszentületi Oktatási Szövetség kötelékébe, a török világ jelei átváltoznak a német világ jeleivé. Ennek ábrázolásában ugyancsak egy sokrétű kulturális kódoltságot hívhatunk segítségül, melynek alapja sok esetben a nemzeti sztereotípia és annak groteszkké tétele: a vilajet, a turbán és a kendő közigazgatási, tárgyi jelölői mellett a néphagyomány kulturális emlékezete is előhívja az ismert gyermekdalt, melynek sorai fizikálisan is megjelenítődnek a diákok fegyelmezése során: a rendbontókat sós kútba teszik, s ha nem tanúsítanak megbánást, kerék alá is teszik. Szintén sztereotip ábrázolás Abu rontott nyelve: idegenként hiányos nyelvi kódot használ (vulgáris helyett „bulgáris", nehezen olvas), mely - belépve az idegenség nyelvi ábrázolásának hagyományába - ugyancsak a humor forrásává válik. A „rendszerváltás” utáni német világban szintén sztereotipnek tekinthető a jóvátétel és a holokauszt megjelenítése, Eszelős Joachim pedig Hitlerre emlékeztetheti az olvasót - ám nem csupán allegorikus szinten, hanem nyelvi-retorikai teljesítményként is. A nyugari törvények kimondják azt is, hogy az iskolában demokratikus választásokat kell tartani, s a diákok is beleszólhatnak abba, ki legyen az igazgatójuk. A demokrácia magával hozza a korrupciót is, Erzsi, az igazgatónő és Gabi, a csapatvezető ádáz harcot vívnak s mindent bevetnek a győzelem érdekében.

\section{Választás és változás}

Az igazgatóválasztás és a hozzá kapcsolódó kampány, lejárató kampány, korrupció talán a drámának leginkább a mai politikai, társadalmi berendezkedéshez kapcsolódó, a reális jeleit alkalmazó része. Erzsi, az iskola igazgatója demokratikus választást szeretne (hiszen ezt kell mutatni a nyugariaknak), ám ellenfele, Gabi tizenhárom szavazata elbizonytalanítja, paranoiássá teszi, s támadásaival, számonkérésével valójában ő maga teremti meg ellenségét. Gabit mindaddig nem érdekli az igazgatói pozíció, amíg Erzsi egyértelmúvé nem teszi, hogy csakis ő lehet az iskola vezetője, s amíg világossá nem válik számára, hogy Erzsit csupán a pozíció, a hatalom, s nem az iskola és az oktatás színvonalának emelése érdekli. Erzsi érzelmi zsarolása (a puszimegvonás) egy ideig eredményhez vezet a diákok körében, ám amikor egy véletlenül kihangosított, CD-re rögzített beszélgetésük nyilvánosságra kerül, eddigi rajongói is elfordulnak tőle, s Gabi, az új jelölt pártjára állnak. A választás elé azonban nehézséget gördít a nemi vetésforgó: női igazgatót csak férfi követhet. Gabinak erre is meglesz a válasza: két hét betegszabadságot kér, ami alatt Nyugarkeresztesen (természetesen mennyei csoda folytán) nőből férfivé válik, így már nincs akadálya igazgatóvá választásának. A választás ezen etapját több feszültség kíséri, mint az előzőt. Míg a darab elején mindenki hallgatólagosan tudomásul vette a demokratikusnak csúfolt szavazás visszásságait, itt már elfojtott indulatok, képmutatás, hazugság övezi (136.): 
"GABI: Szóval, szeretnék igazgató lenni, és kérem egy rendkívüli igazgatóválasztás kiírását!

Csend.

ERZSI: Gabikám... Mosolyogva. A kurva anyádat! Hogy mit kérsz te, kis bogaram?

GABI: Rendkívüli igazgatóválasztást még ezen a héten.

ERZSI: Rendkívüli igazgatóválasztást? Milyen rendkívüli igazgatóválasztást, te tébolyult, idióta, hülye, te?"

A leleplezett Erzsi a diákok előtt igyekezett megőrizni renoméját, továbbra is anyáskodóan (bár kétségtelenül lekezelően) beszélt velük, ám az új választás lehetősége megtöri tartását, képtelen mondatait irányítani, a szöveg stílustörése egyben Erzsi megtörését is jelzi. A rendkívül erős indulatszavak előtt ugyan mosolyogni próbál, ám ez inkább érzelmeinek (nem túl sikeres) leplezését szolgálja. Gabi szerint a nappal a keresztény Istenhez, ám este Allahhoz imádkozó Erzsi „egy személyben testesíti meg a múlt minden sötét betokosodottságát". (137.)

A politikai folyamat szép allegóriája a választás utáni események láncolata: a nyertes Gabi (immár Gábor) lefokozza Erzsit, aki először tanítónővé, majd diákká változik, illetve megszünteti a kapcsolatot a nyugariakkal, s első estéjén máris az oszmánokhoz fordul, akik kedvezőbb áron biztosítják számukra az étkezést. A változást generáló nagy eszmék máris megkérdőjeleződtek, a demokráciánál és a szabadságnál fontosabbá válik az állománykassza egyensúlyban tartása, a minél nagyobb nyereség bezsebelése. Az új kapcsolat örömére pedig Második Szelim az iskolába fog látogatni (146.):

„GABI: Nyugalom, gyerekek! Ez a kapcsolat kizárólag az étkeztetésre vonatkozik majd! És különben is, ne féljetek, amíg engem láttok! Ha az a pasa mond valami rosszat a simonosokra, adok neki egy akkora pofont, hogy lerepül a turbán arról a gölödin fejéről. [...]

Szóval nem kell megijedni! Ez egy baráti, jó hangulatú találkozó lesz! [...] Természetesen nem kell majd turbánt meg fejkendőt viselni... Ööö... A szerződés lesz itt elsősorban fontos, ami jó lesz nekik is, nekünk is... A jószomszédi viszony nekik is fontos..."

Végigkövethetjük, ahogyan Gabi az igazság bajnokából egy behódoló, iskoláját eladó vezetővé válik. Immár nem a demokrácia áll elvei középpontjában, határozottsága ugyanúgy alábbhagy, mint az Erzsié, mondatai hiányosak, sok esetben logikátlanok, töltelékszavakat használ, hiszen nem tudja pontosan meghatározni, a nyilvánosság számára logikusan felépíteni, miért is fordult ily hirtelen régi ellenségükhöz az üdvös és felszabadító nyugariak helyett. 
Igaz, néhány elvhez, melyeket már az első igazgatóválasztáson is képviselt, ragaszkodik, ilyen például a diákokkal való emberi viselkedés, a kiabálás mellőzése, hiszen ezek voltak számára (és a diákok számára is) az elnyomás elsődleges jelei. Ha e jelek megszűnnek, megszűnik az elnyomás is - gondolhatja a naiv befogadó. S pusztán a színfalak mögött játszódik a korrupció - mely az iskola egyszerű gyermekei számára irreleváns, hiszen nem válik mindennapjaik részévé, zárt világukat nem befolyásolja. A jobb étkeztetés, a direkt erőszak hiánya tökéletesen felkínálja a „Kenyeret és cirkuszt!" illúzióját.

Gabi/Gábor hamar átlátja, hogy a szabadság és a demokrácia sem tesz mindent lehetővé, így ő is - ahogyan korábban Erzsi - a képmutatás gazdag eszköztárához nyúl, s erre biztatja az ifjú, forrófejü, a politikai-társadalmi elvárásokat és szokásrendet még nem ismerő Gyöngyit is. „GABI: [...] Hidd el, hogy mi ketten teljesen egyformán gondolkodunk! Például, én is utálom a Gazsó Nellit, de nyugariak vagyunk, és egy-két dologban sajnos meg van kötve a kezünk." (150.)

Gabi, hatalmi pozíciójába immár egyre inkább belehelyezkedve, megzsarolja Gyöngyit, aki - közel sem önszántából - Gabi menyasszonya, majd felesége lesz, s nemcsak a Hajvántól kapott nyakék felkínálása inspirálja döntését, hanem a burkolt fenyegetés is.

Az esküvői szertartáson már körvonalazódik, hogy Gabinak ugyanolyan saját törvényei vannak, mint Erzsinek voltak, a házasságkötést ő maga celebrálja, sem az állam, sem az egyház, hanem a Simon Ferenc törvényei értelmében cselekszik, melyeket ő alkothatott.

A politikai-hatalmi játszma csúcspontja Második Szelim látogatása, mely sajátos szituációba, újabb szerep felvételére kényszeríti Gabit. Az elűzött, majd visszahívott zsarnok nem alázkodik meg Gabi előtt, a viszonyuk a régi időket idézi, hiszen Szelim tudja, hogy Gabinak szüksége van az ő közétkeztetésére. Az allegória lehetősége itt is folyamatosan jelen van, Szelim oroszos akcentussal beszél, egy nagy birodalom ura, míg Gabi csak egy iskolát igazgat, mely elszakadt ugyan a birodalomtól, de ugyanúgy a kiszolgáltatottja, mint korábban. Szelimnek továbbra is nagy hatalma, s ami ezzel szorosan összefügg, sok katonája, fegyverese van, így akkor, amikor lelepleződik, hogy Gabi sós kútba tetette Hajvánt, aki ott el is pusztult, kegyetlen bosszút áll testvéréért: lelöveti a menekülő Gabit és Abut.

Ám a hatalom természetrajzának megfelelően csak a neveket és a címkéket kell kicserélni: az igazgatói fejdísz immár Gyöngyi fejére kerül, aki egy kicsit fiatalabb, egy kicsit másabb, de lényegében semmit sem változtat az eddigi hatalmi narratívákon (156.):

„GYÖNGYI: Az iskola veszélyben van! Harangokat félreverni, és homokzsákokat a kapukhoz! Gyerünk, gyerünk, minden kapuhoz homokzsákokat, most rögtön! A többiek teljesítik a parancsait. A sparheltre forró vizet és szurkot, ha megtámadják az intézetet, az Egri Vár védőihez hasonlóan tudjunk védekezni! 
Ettől a pillanattól rendkívüli állapotot hirdetek! Mindenkinek engedelmeskednie kell, aki pedig nem engedelmeskedik, rögtönítélő bíróság elé kerül! [...]"

Gyöngyi egy pillanat alatt belehelyezkedik új szerepébe, ám sejthető, hogy vezetői kvalitásai nem fognak eredményre vezetni, a helikopteres, géppisztolyos törökök ellen igen keveset fog érni a homokzsák vagy a forró víz.

A dráma politikai-társadalmi rétege kínálja a legdirektebb, legpontosabb allegorikus értelmezés lehetőségét, ám óvatosan kell bánnunk a direkt allegorézissel. Ennek magyarázatához vizsgáljuk meg még néhány, akár toposzként, akár kicsinyítő tükörként müködő képet vagy képrendszert, hogy végül összeszőhessük az allegorikus hálót.

\section{A szürke eminenciás}

A társadalmi-politikai háttér fontos figurája a szürke eminenciás, mely szerepet Abu, a török származású technikatanár veszi magára. Abu túlélt eddig minden rendszert, mindenhol megtalálta a számítását, hol magát meghúzva, hol kisebb-nagyobb stiklijeivel (147.):

„ABU: Persze! Itt történik az, amit én akarok! Így volt ez Geci Imre idejében is, a geci Erzsi idejében is, de a Gabi is geci. Ő is rábaszhat, ha nem tisztel engem! De mindenki! Az Andreas von Bruckner, meg Szelim Pasa is úgy fütyül, ahogy én táncolok nekik!"

Abu felvázolt szerepe akár igaz is lehet, ám kissé elbizonytalanítja pozícióját a közmondás logikai rendjének megfordítása: hiszen eszerint a két említett vezető fütyül, ő pedig táncol, azaz nem ő irányít, csak ügyesen szolgál minden urat.

Bár Abu nem vágyik vezérszerepre (ahogyan általában a szürke eminenciások sem), egyik leghőbb vágya, hogy megvehesse a hatalmas tenyésznyulat, Gabi igazgatósága alatt teljesül. Gond csupán akkor adódik, amikor a nyúl eltűnik, s Abu a szökött törököt, Hajvánt gyanúsítja azzal, hogy felfalta az állatot. Ahogy feljebb láthattuk, Hajván sós kútba kerül, ami a nyugari paradigmában betiltott büntetésmód, így Abunak - szürke eminenciáskét - elleneznie kellett volna, ám a korábban jól kombináló technikatanár józan döntését jócskán befolyásolta saját kedvencén, a nyúlon esett sérelem. Abu sorsa ezzel megpecsételődik, a hatalom legerősebb embere, Második Szelim őt is lelöveti. 


\section{Üres helyek}

A dráma mint performatív jelenség nem akar mindent megmagyarázni, felfejteni, számos megmagyarázatlan jelenséggel, balladai (vagy éppen drámai) homályba burkolódzó cselekménnyel találkozunk. Nem kapunk egzakt beszámolót Erzsi haláláról, Abu abban játszott szerepéről, de jelzésként van jelen a kábítószer-kereskedelem oka és következménye, vagy éppen Abu nyúltartása is. Gabi Gáborrá változását is rejtélyként értelmezhetjük, de ugyanígy harcos demokrata-feministából zsarnokká válását is. A zárószakasz egyik kulcsjelenete is nyitott kérdésként jelenik meg: ki ette meg a nyulat? Hajván tette indokoltnak túnhet, ám mire idáig érünk, már minden más szereplő is bűnösnek mondható, azaz az olvasó/néző könnyen feltételezheti, hogy bárki elkövethette a „bűntényt", vagy éppen intézhette úgy, hogy a gyanú Hajvánra terelődjön.

Az üres helyek közé sorolhatjuk azokat a jelenségeket és kijelentéseket is, melyek igazságértéke vagy már eleve kérdéses, vagy a mű során relativizálódik. Nem egyértelmű az előző igazgató, Géczi/Geczi diktatúrában betöltött szerepe (de még neve helyesírása) sem, nem tudjuk meg, valójában tolvaj volt-e Gabi a háremben, vagy valóban a feminista szemináriumok miatt kergették el.

Ezek az üres helyek viszont nem kedveznek a direkt allegorézisnek: sokkal inkább arra hívják fel a figyelmünket, hogy a hiányzó képeket (okokat, motivációkat, összefüggéseket stb.) az olvasónak, nézőnek kell belehelyezni a darabba, ezáltal viszont olyan saját és sajátos motivikus rendszerek jönnek létre, melyek sokkal inkább kedveznek a szimbolikus olvasásnak, mint az allegorikusnak.

\section{Irodalmi párhuzamok}

A mú olvasása számos drámaélményt előhívhat, most ezek közül csupán egyet emelnék ki, mely felkínálja az együttolvasás és -gondolkodás termékeny folyamatát. Brechttől $A$ szecsuáni jólélek című drámával rögtön tematikus egyezést is fel tudunk mutatni: a darab főhőse, Sen-Te nem tudja máshogy megoldani egzisztenciális és morális problémáit, csak úgy, ha "férfivá válik", azaz kitalál magának egy nagybácsit, Sui-Tát, aki néha felbukkan férfiruhában, s rendet tesz ott, ahol Sen-Te nőként képtelen boldogulni. Ám a Fácántáncban sem Gabi, sem Erzsi, sem Abu nem küzd morális problémákkal, lelkiismeretük nem szólal meg, nem akarnak jók lenni abban az értelemben, ahogyan Sen-Te törekszik a jóságra. Gabi férfivá válását sem magyarázhatjuk jóra való törekvésével. Bár Sui-Ta is a kényes és nőként (társadalmi lehetőségeit tekintve) megoldhatatlan problémák kezelésére született, fontos különbség, hogy eközben megmaradt Sen-Te is, míg Pintér darabjában a korábbi Gabit teljesen megszünteti Gábor jelentkezése. A világirodalomban (különösen a drámákban és mesékben) több helyen is találkozunk a szükségszerű nemváltással, általában akkor, amikor a hős addig elfojtott személyiségjegyei segítségével tudja csak megoldani a kialakult helyzetet. A rend helyreállása után azonban az így előhívott (nők eseté- 
ben a férfiasságot erősítő) archetipikus elemek a háttérbe szorulnak, hogy újra átadják helyüket a személyiség uralkodó archetípusának. Gabinál nem történik meg a visszatérés, ebből akár arra is következtethetünk, hogy a szerepszemélyiség átvette az uralmat a szubjektum fölött, vagy éppen a most uralomra jutó személyiségrész tekinthető az uralkodó archetípusnak.

E motivikus párhuzam mellett ugyancsak jelentős lehet a Brecht-mú egyik nyitómetaforája: „A történetben szereplő Szecsuán tartomány, amely mindazon helyeket képviseli, ahol embert ember kizsákmányol, ma már nem tartozik az ilyen helyek közé." ${ }^{3} \mathrm{Az}$ allegória így részmegfeleléseket mutathat, a Simonban is parancsszóra, választási lehetőség nélkül élnek a diákok, akik lényegében fiatal vagy idősebb felnőttek, mégis be vannak zárva egy infantilitásba süllyedt közegbe. Jogaik nem többek a gyerekek jogainál, önálló döntéseik legfeljebb csínyek, mint ahogyan a totalitárius rendszerek készen kínált ideológiái sem kívánnak sem önálló gondolkodást, sem önálló cselekvést az emberektől. A felsőbb diktatúrán belül zárt diktatórikus rendszerek alakulnak ki, a külsőhöz igazodó saját, belső szabályokkal, melyek valójában nem felülírják, inkább megerősítik s életben tartják a külső, felsőbb szabályokat.

Ahogyan Brecht darabjában, itt sem kapunk valódi megoldást, a (rendszer-) váltások nem hoznak valódi változást. Sen-Te semmitmondó választ kap az istenektől, mely nem segíti őt döntéseiben, így kiderül, az istenek sem tudják megoldani a problémákat. „Tisztelt közönség, kulcsot te találj, / Mert kell jó végnek lenni, kell, muszáj" - hangzik el a dráma immár szállóigévé vált zárlatában, így a megoldás lehetősége a művön kívüli világba, a befogadóéba helyeződik át. Pintér darabja az ismétlődő allegorikus mintákkal (Erzsi, Gabi majd Gyöngyi igazgatóságával) egyfajta körforgásra hívja fel a figyelmünket, olyan világra, ahol embert ember kizsákmányol, s ennek ritmikus ismétlődése válaszként is szolgálhat a felvetődő kérdésekre: ahogy Brechtnél sem tudják az istenek sem elsimítani a világban jelen lévő visszásságokat, a Fácántánc sem oldja fel a feszültséget, nem kínál feloldódást a mű pragmatikai terében. E motívum előhívhatja egy másik drámaélményünk tapasztalatát: Ionesco $A$ kopasz énekesnő címú abszurd drámája az értelmetlen cselekedetek, a helyettesíthetőség vagy éppen a körkörösség (újrakezdődik minden, csak újabb szereplőkkel) metaforarendszerén keresztül léphet párbeszédbe Pintér drámájával.

\section{Ritmus és zene}

Ahogyan Pintér Béla darabjaiban már megszokhattuk, a Fácántáncban is jelentős szerepet kap a zene, a dalok jelenléte. A szöveg poétikai ritmikussága mellett formai keretként jelennek meg népdalátiratok (az Elment a két lány virágot szedni dallamára recitálja Nelli és Gyöngyi a mű bevezető sorait, ismertetik meg

3 Bertolt BreCHT, "A szecsuáni jólélek”, ford. Nemes Nagy Ágnes, in Bertolt BReCHT, Drámák, 227-352 (Kaposvár: Holló és Társa Könyvkiadó, 1996), 229. 
az olvasóval/nézővel az aktuális történelmi, társadalmi állapotokat (113.), vagy ugyanezen dal átirata hallható Pötyitől is, melyben Gabi néni csodás átváltozását énekli el. (133.) A gyerekek e szituációkban krónikásszerepet vesznek fel, ők azok, akik - akár Tinódihoz hasonlóan, aki éppen a törökellenes végvári harcok dalnoka volt - pontosan és aktuálisan tudósítanak az eseményekről. (Az már az olvasóra lesz bízva, mennyire hisz egy krónikásnak.) Ugyancsak önmagán túlmutató jelentéssel bír a felcsendülő Rákóczi-induló, mely a hajdani mozgalmi rendezvények népszerű dallamát idézi fel, vagy az El Condor Pasa a maga eklektikus new age-es romantikájával. E dallamra íródott a Simon híres himnusza, a perszonális szent fácántánc, mely a beavatási ceremóniát is kíséri. E himnusz emellett zeneműként és szöveghelyként is megidézi Kölcsey Himnuszát is, illetve a katolikus liturgia sorai is szervezőelemeivé válnak (117.):

„ERZSI: $A z$ „El Condor Pasa" dallamára.

Ó kérlek, Isten, nézz le lányodra!

Nézz rám! Tekints rám!

Itt áll egy fácán.

Két pálcán.

Ó kérünk Isten, áldd meg a Simont!

Jó kedvvel, bőséggel!

Segítsd a tanulást!

Könyörgünk!

Balsors akit régen tép, hozz rá víg esztendőt!

Megbűnhődtük mi már rég a múltat és a jövendőt.

Múltat, s a jövendőt.

Már rég.

Az egyre fokozódó zenére tesz még egy diadalmas kört, majd visszasétál a helyére.

Az Úr legyen veletek!

MIND: És a te lelkeddel!"

A zenei átiratok mellett felcsendül a műben az Örömóda Beethoven IX. szimfóniájából, az I/ silenzio, a Nászinduló, de halljuk a müezzin énekét, a Gólya, gólya, gilicét munkadalként, megidéződik a Katalinka, szállj el! a Simon büntetéseiben, majd folklorisztikus török technó teszi teljessé az egyre kaotikusabbá váló „krónikát". A dallammal kísért előadásmód könnyedsége, a populáris és a magas kultúra regisztereinek keverése, a sajátosan értelmezett tradicionális énekek a mű imaginárius világában továbberősítik az abszurd jelleget, miközben az ismerősség kényelmes miliőjével is megajándékoznak minket. 


\section{Az allegorikus hálók összeszövése}

Az olvasó, néző a fentebb felvázolt allegorikus rendszerek bármelyikébe, mindegyikébe kényelmesen bele tud helyezkedni, ám kétségtelen, hogy egyik nem létezhet a másik nélkül. Mint minden, társadalmi kérdést is érintő mú esetében, itt is kínálná magát a direkt allegorézis, azaz a mú eseményeinek, hőseinek átfedő megfeleltetése a korszak politikai, társadalmi eseményeivel, szereplőivel. Természetesen ez az eljárás nem lehetetlen, ám az aktuálpolitika képpé és szöveggé tételén túl sokkal összetettebb rendszert kínál a darab. (Emellett persze azt is érdemes szem előtt tartani, hogy az aktuálpolitikai párhuzamok hamar elhalványulnak, s míg az abszolút kortársaknak számos kapcsolódási pontot kínálhatnak a dráma megértéséhez, idővel jelentés nélkülivé válnak jeleik.)

Pintér múve képes túllépni e nehézségen: úgy kínál kortárs (allegorizáló) olvasatot, hogy közben összetettsége révén túl is lép azon. Míg egyik allegorikus szinten minden olyan hely képviselőjévé válik, ahol embert ember megaláz, szimbolikus-anagogikus szinten, világirodalmi, zenei, motivikus, müfaji vagy éppen lélektani utalásainak, párhuzamainak köszönhetően kitágítja e világot is, így válik allegorikus szálak szövevényes hálójává, melyben a jelenkor - és a reménybeli jövendő - befogadói folyton újraképződő, saját jelentéseket szőhetnek. 